\title{
CHLORIDE DEPLETION IN CONDITIONS OTHER THAN ADDISON'S DISEASE ${ }^{1,2}$
}

\author{
BY ALEXANDER W. WINKLER AND ORRIN F. CRANKSHAW \\ (From the Department of Internal Medicine, Yale University School of Medicine, and the \\ Medical Service of the New Haven Hospital, New Haven)
}

(Received for publication July 9, 1937)

This report is concerned with certain types of chronic salt depletion differing from those seen in Addison's disease and in nephritis. By salt deple-

1 Read before the twenty-ninth meeting of the American Society for Clinical Investigation, May 3, 1937.

2 This investigation was aided by a grant from the Fluid Research Fund of Yale University, School of Medicine. tion is meant the presence in the blood serum of abnormally low concentrations of chloride, of sodium or of both ions.

\section{METHODS AND MATERIALS}

The subjects were patients on the hospital wards. Chemical methods employed were those in customary use in this laboratory $(1,2)$. Chlo-

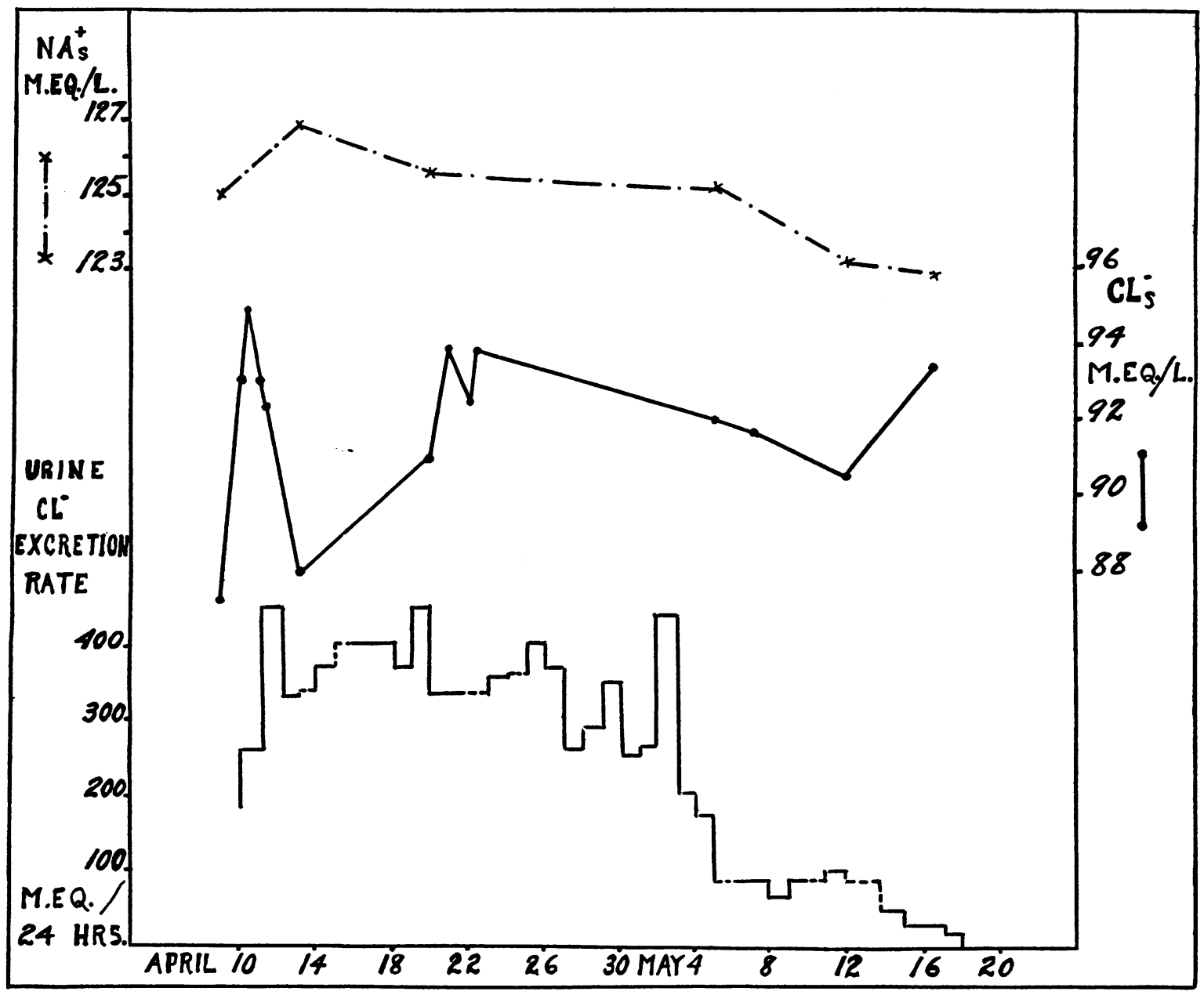

Fig. 1. Pulmonary Tuberculosis

Persistent excretion of chloride in the urine associated with deficit of chloride and of sodium in the serum. 


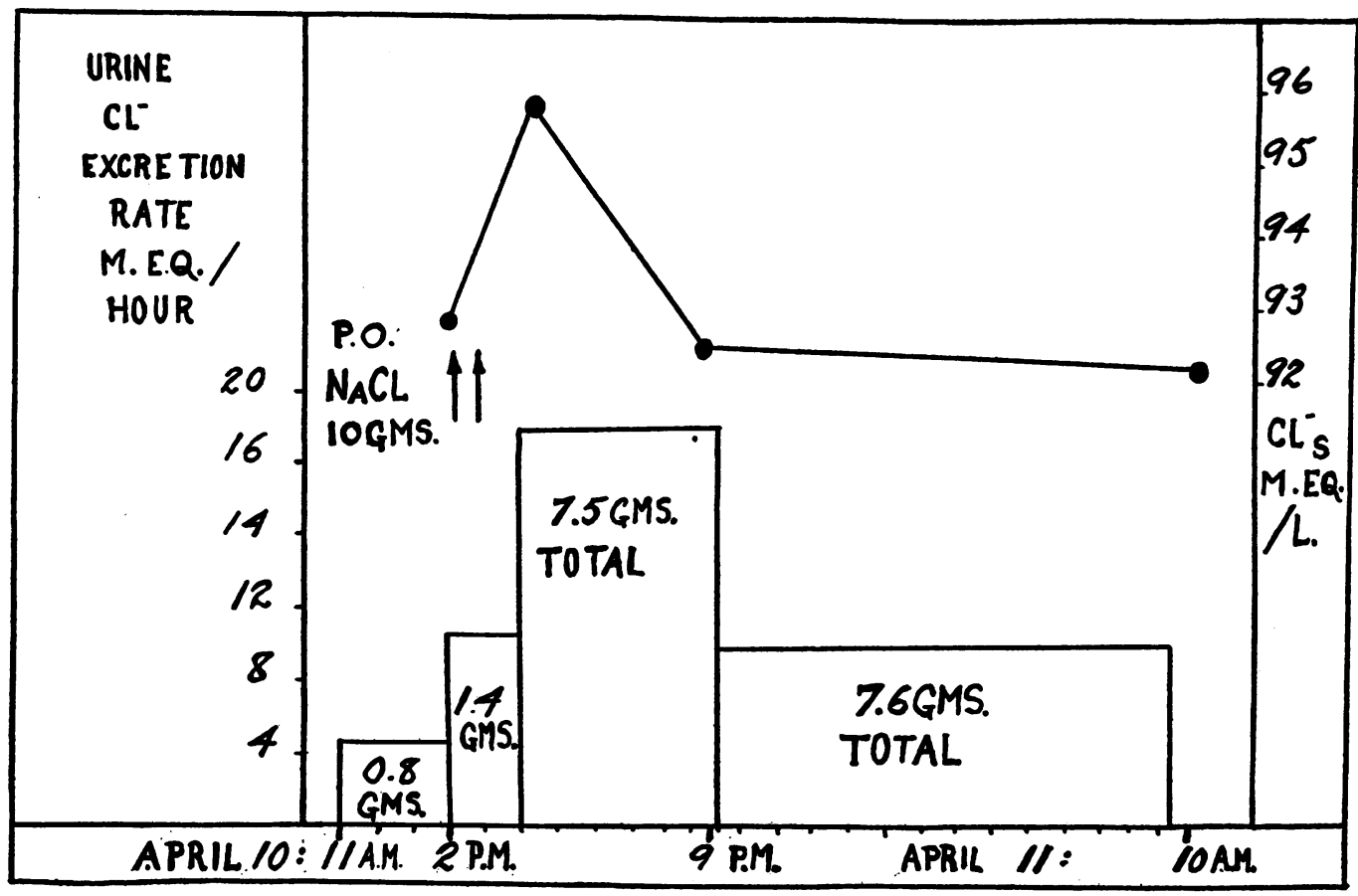

Fig. 2. Subject of Figure 1

The immediate effect of the oral administration of 10 grams of $\mathrm{NaCl}$.

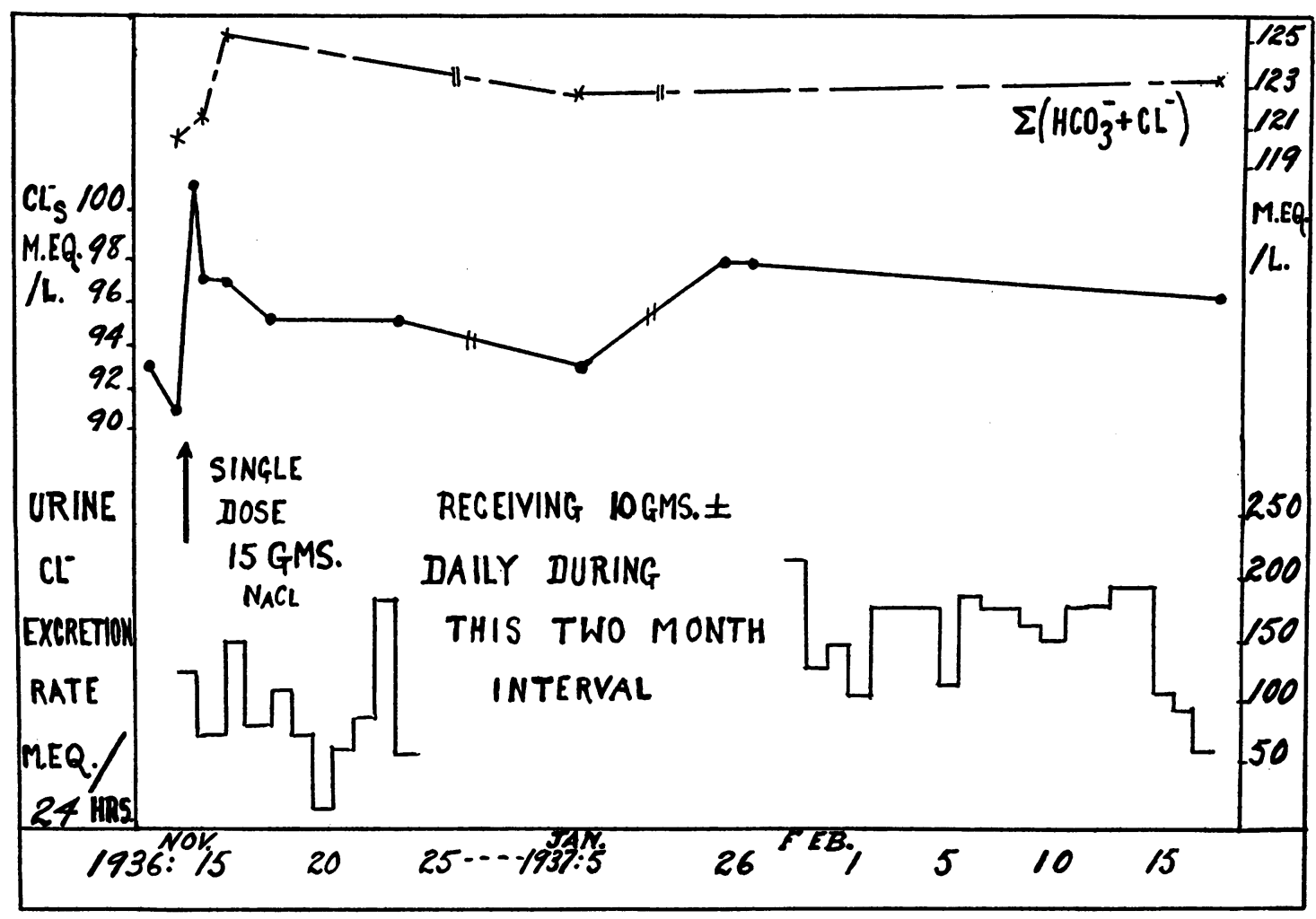

Fig. 3. Pulmonary Tuberculosis

Persistent chloride excretion in the urine associated with deficit of chloride in the serum. 
ride of the serum was always directly determined, and in many instances the sodium was likewise directly determined. In certain of the studies the sum of the chloride and of the bicarbonate was used as a measure of the sodium concentration. Chloride alone was determined in urine.

\section{RESULTS}

The significant data of the first case are presented in Figure 1. This patient suffered from acute pulmonary tuberculosis which led to his death within a few weeks. At autopsy, the adrenal glands and the kidneys were entirely normal. Throughout his course the concentrations of chloride and sodium in the serum remained at definitely subnormal levels in spite of the daily administration of large amounts of salt, and in spite of the absence of vomiting, diarrhea, or excessive sweating. A study of the urinary excretion of $\mathrm{Cl}$ reveals the fact that very large amounts of salt were excreted in the urine while the concentrations of both sodium and chloride in his serum remained far below normal levels. In Figure 2 the immediate effects of a single dose of 10 grams of salt are analyzed. The concentration of chloride in the serum rose only to 96 m.eq. per liter and then fell rapidly back to its previous level, while at the same time the chloride was being excreted at a high rate in the urine. Parenthetically, the intravenous administration of cortical extract had no effect on the salt excretion in this case.

In Table $I$ and in Figure 3 are shown the results of studies of the sera of a group of 13 other patients with pulmonary tuberculosis. In the majority of the cases the serum $\mathrm{Cl}$ was at or below

TABLE I

Serum studies in thirteen additional subjects with pulmonary tuberculosis

\begin{tabular}{|c|c|c|c|c|c|}
\hline Case & Date & $\mathrm{HCO}_{3}^{-}$ & $\mathrm{Cl}^{-}$ & $\mathrm{Na}^{+}$ & Remarks \\
\hline & & $\begin{array}{l}\text { m. eq. per } \\
\text { lisier }\end{array}$ & $\begin{array}{l}\text { m. eq. per } \\
\text { liter }\end{array}$ & $\begin{array}{l}m . \text { eq. per } \\
\text { liter }\end{array}$ & \\
\hline $1^{*}$ & April 22, 1936 & 27.1 & 88.6 & & $\begin{array}{l}\text { Salt added. } \\
\text { Advanced tuberculosis. }\end{array}$ \\
\hline $2 \dagger$ & $\begin{array}{l}\text { Feb. 18, } 1935 \\
\text { Feb. 20, } 1935\end{array}$ & $\begin{array}{l}25.0 \\
29.1\end{array}$ & $\begin{array}{l}94.5 \\
89.5\end{array}$ & $\begin{array}{l}125.2 \\
126.1\end{array}$ & Low salt diet between studies. \\
\hline $3 \ddagger$ & April 4, 1936 & 22.8 & 87.2 & 119.6 & Salt ad lib. \\
\hline 4 & July 11, 1935 & 27.9 & 97.3 & & Afebrile; undernourished. \\
\hline 5 & $\begin{array}{l}\text { March 30, } 1936 \\
\text { May 6, } 1936\end{array}$ & $\begin{array}{l}23.9 \\
24.0\end{array}$ & $\begin{array}{l}94.5 \\
95.1\end{array}$ & & $\begin{array}{l}\text { Febrile; severe tuberculosis } \\
\text { Low salt } 24 \text { hours before second study. }\end{array}$ \\
\hline 6 & April 28, 1936 & 30.1 & 96.7 & & Afebrile. Salt ad lib. \\
\hline 7 & $\begin{array}{l}\text { Nov. } 18,1936 \\
\text { Nov. } 20,1936\end{array}$ & & $\begin{array}{l}92.2 \\
99.1\end{array}$ & & $\begin{array}{l}\text { Second study just after receiving } 15 \text { grams } \mathrm{NaCl} \\
\text { orally. }\end{array}$ \\
\hline & $\begin{array}{l}\text { Nov. } 21,1936 \\
\text { Nov. 24, } 1936\end{array}$ & & $\begin{array}{l}99.1 \\
92.9\end{array}$ & & $\begin{array}{l}\text { During Nov. and Dec. } 1936 \text { received daily } 10 \text { grams or } \\
\text { more of } \mathrm{NaCl} \text { orally. }\end{array}$ \\
\hline & Jan. 5, 1937 & 28.7 & 96.6 & & \\
\hline 8 & Nov. 12, 1936 & & 99.3 & & Salt ad lib. \\
\hline 9 & Nov. 19, 1936 & & 98.7 & & Salt ad lib. \\
\hline 10 & Feb. 2, 1937 & & 98.1 & & Salt ad lib. \\
\hline 11 & $\begin{array}{l}\text { Jan. 27, } 1937 \\
\text { Feb. 2, } 1937\end{array}$ & 25.7 & $\begin{array}{r}102.3 \\
97.7\end{array}$ & & Receiving 10 grams $\mathrm{NaCl}$ daily in the interval. \\
\hline 12 & April 7, 1937 & 27.4 & 102.7 & & Salt ad lib. \\
\hline 13 & May 16, 1937 & 25.6 & 97.0 & & Salt ad lib. \\
\hline
\end{tabular}

* Normal adrenals at autopsy.

† One caseous tubercle in one adrenal at autopsy. Otherwise adrenals normal.

$\ddagger$ Both adrenals showed caseation involving two-thirds of their substance. 
the lower limit of normal. Of the three autopsied cases only one showed significant adrenal disease, and in this one the destruction of the adrenals was not extreme. Of those not autopsied none had clinical evidence of Addison's disease or nephritis. Another case with persistent hypochloremia presented in Figure 3 was selected for a study of the relationship of this $\mathrm{Cl}$ deficit to urinary $\mathrm{Cl}$ excretion. A type of behavior similar to that of the first case is manifest, but to a less marked degree. The administration of a single large dose of salt did raise the serum $\mathrm{Cl}$ level to normal for a few hours. The increase was, however, not maintained, the serum concentration rapidly falling to subnormal levels with continuing urinary excretion of salt. Followed over a period of three months the $\mathrm{Cl}$ level remained persistently low in spite of the daily intake and urinary output of ten or more grams of salt.

In Figure 4 are presented the data from a case of chloride depletion in a subject with primary carcinoma of the lung and secondary mycotic infection. There was no evidence of tuberculosis. Here both $\mathrm{Cl}$ and the $\mathrm{Na}$ of the serum were lower than normal, but the $\mathrm{Cl}$ was diminished more than the $\mathrm{Na}$. This was reflected in a persistent slight increase in the serum bicarbonate. In this case the depletion was also occasioned by the persistence of urinary chloride excretion at abnormally low serum concentrations. While the patient was on a salt-poor diet, intravenous infusions of 15 grams of $\mathrm{NaCl}$ were given on two occasions.

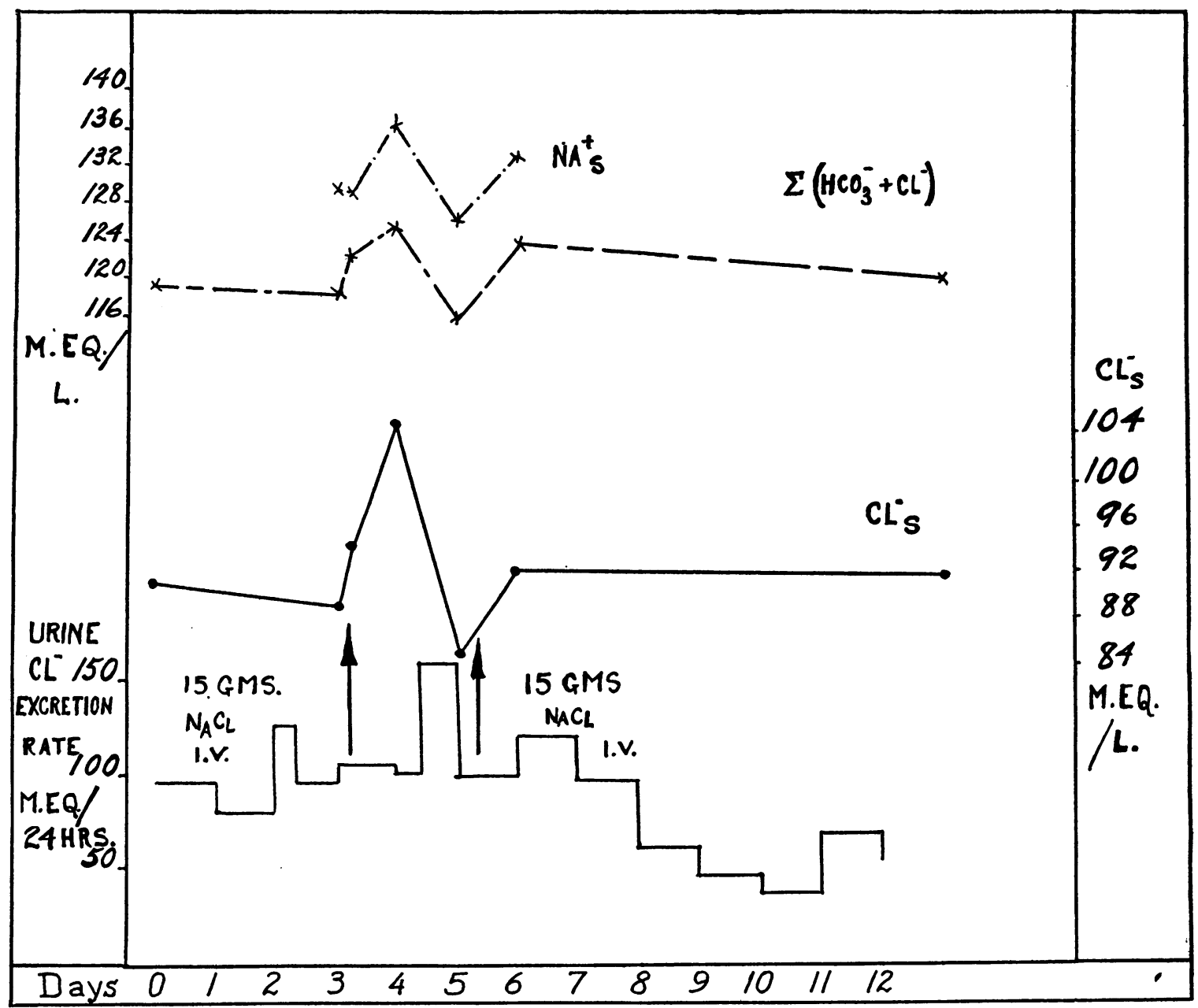

Fig. 4. Carcinoma of the Lung

Persistent chloride excretion in the urine associated with deficit of chloride in the serum. 


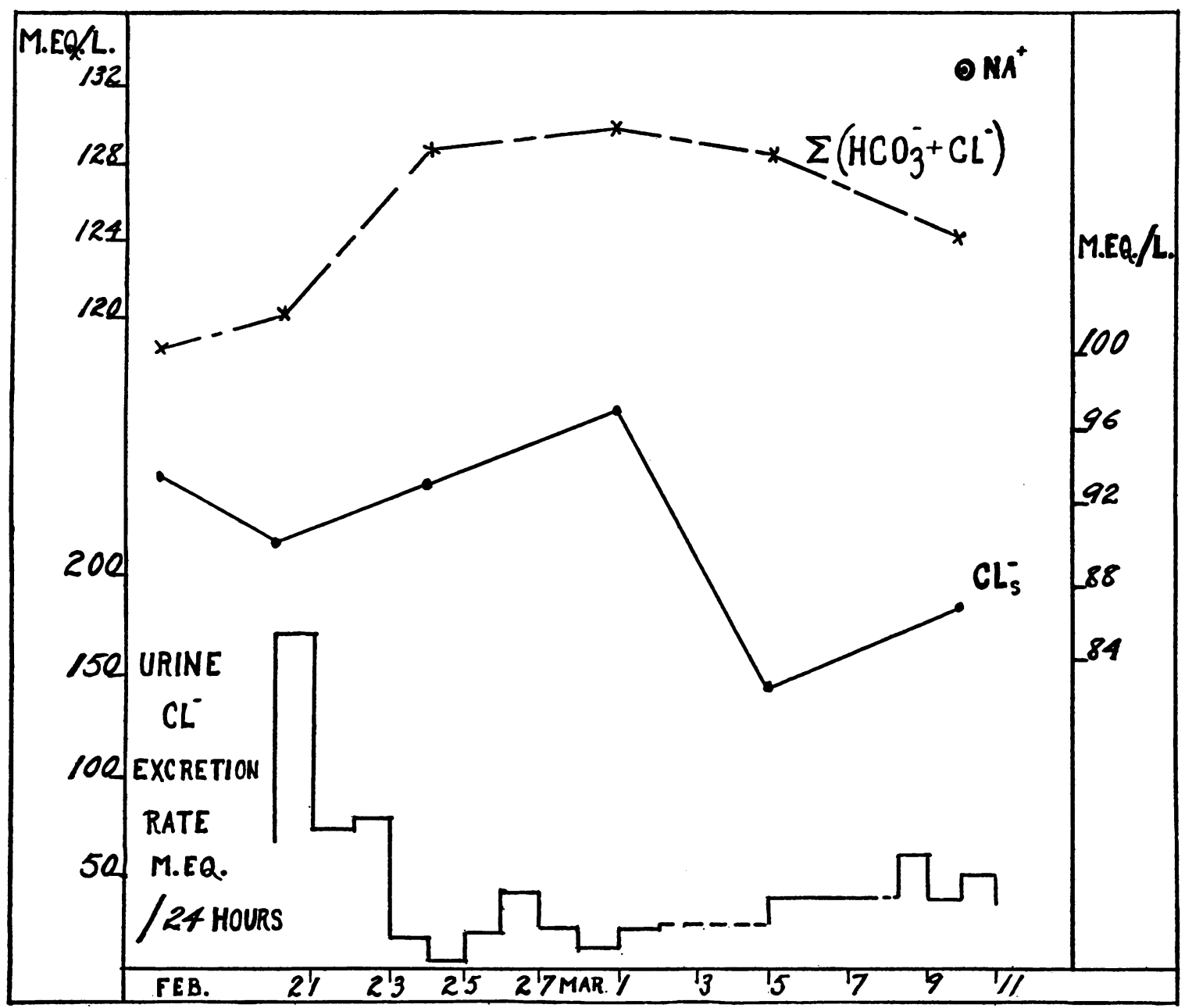

Fig. 5. Arteriosclerotic Heart Disease with Congestive Failure

Excretion of chloride in the urine associated with chloride deficit in the serum.

These resulted in transitory increases of the serum chloride which were not maintained, large amounts being rapidly excreted in the urine until the serum concentration had lapsed to its old level.

In Figure 5, certain very similar data from a case of arteriosclerotic heart disease with emphysema and some congestive failure are presented. Autopsy at a later date revealed no serious renal damage and no suprarenal disease. The serum sodium concentration was normal and the serum chloride concentration low throughout most of the course of this patient. The serum bicarbonate was correspondingly high. The peculiar electrolyte pattern was interpreted as a result of so-called "primary" $\mathrm{CO}_{2}$ excess in which the pathological condition of the lungs hinders the free escape of
$\mathrm{CO}_{2}$ from the blood (3). This is in a sense compensated by a depression of the serum $\mathrm{Cl}$ without concomitant depression of base. This depression of serum $\mathrm{Cl}$ must, however, be mediated through the kidneys. In this subject, $\mathrm{Cl}$ was excreted in considerable quantities in the urine while the serum $\mathrm{Cl}$ level remained persistently depressed, thus providing a mechanism by which such a $\mathrm{Cl}$ deficit could be produced and maintained.

\section{DISCUSSION}

All the cases in the somewhat heterogeneous group which we have presented have in common the ability to excrete considerable amounts of $\mathrm{Cl}$ in the urine at times when the serum $\mathrm{Cl}$ concentration is at a level at which $\mathrm{Cl}$ excretion normally 
virtually ceases. All showed some degree of salt deficit, which was brought about through the operation of this peculiar alteration in renal status.

The fact that they all had pulmonary lesions may well have been fortuitous. Serum $\mathrm{Cl}$ deficit in pulmonary tuberculosis has been reported before (4), and apparently is correlated neither with the severity of the disease nor the extent of the lesion. It is interesting, however, to note the similarity in chloride behavior of the other cases to the cardiac case with primary $\mathrm{CO}_{2}$ excess, in which we have some reason to believe that the renal alteration is a direct and compensatory reaction to the pulmonary disease.

These cases have something in common with the type of acute chloride depletion seen in lobar pneumonia, in which as Sunderman (5) and Wilder and Drake (6) have shown there may at times be some tendency towards a urinary wastage of salt at low levels of serum base and $\mathrm{Cl}$. Characteristically, however, in the hypochloremia of pneumonia there is almost complete retention of administered salt with very little urinary excretion even after large doses-behavior exactly opposed to that seen in the group of cases here described.

The intimate mechanism whereby the normal renal threshold for chloride excretion is depressed is not known. For the present, we can simply recognize the existence of types of chronic salt depletion which are mediated through such a mechanism. They do not fall into any.of the commonly recognized groups in which depression of the renal threshold for salt may occur, such as nephritis or Addison's disease. The practical value of such recognition may be great in the differential diagnosis of the latter condition, since evidently the occurrence of a low serum $\mathrm{Cl}$ or $\mathrm{Na}$ after salt withdrawal by no means signifies Addi- son's disease. This is especially important since it is precisely in the tuberculosis group of patients that Addison's disease is likely to be suspected. Finally, the suggestion that there is a possible physiological mechanism linking lung and kidney in relation to salt merits further exploration.

\section{SUMMARY AND CONCLUSIONS}

1. A state of chronic depletion of the serum chloride is described in certain cases of pulmonary tuberculosis, carcinoma of the lung, and cardiac disease.

2. This chloride depletion results from the ability of these subjects to excrete chloride readily in the urine at levels of serum chloride at which urinary excretion of the ion normally virtually ceases.

3. This behavior in these subjects is not associated with recognizable anatomical disease of the suprarenal glands or kidneys.

\section{BIBLIOGRAPHY}

1. Peters, J. P., and Van Slyke, D. D., Quantitative Clinical Chemistry. Volume II. Methods. Williams and Wilkins Co., Baltimore, 1932.

2. Hald, P. M., The determination of the bases of serum and whole blood. J. Biol. Chem., 1933, 103, 471.

3. Peters, J. P., and Van Slyke, D. D., Quantitative Clinical Chemistry. Volume I. Interpretations. Williams and Wilkins Co., Baltimore, 1931.

4. Müller, P., and Quincke, $H$., Untersuchungen über den Stoffwechsel bei Tuberkulose. III. Tuberkulose und Chlorstoffwechsel. I. Deutsches Arch. f. klin. Med., 1928, 158, 62.

5. Sunderman, F. W., Studies of serum electrolytes. IV. The chloride and nitrogen balances and weight changes in pneumonia. J. Clin. Invest., 1929, 7, 313.

6. Wilder, T. S., and Drake, T. G. H., Metabolism of chloride and total fixed base in pneumonia and the relation to salt and water retention. J. Clin. Invest., 1929, 7, 353. 